\title{
養殖ブリ黄疸の病態生理
}

\author{
前野幸男・中島員洋・反町稔・乾 靖夫
}

（1994 年 4 月 13 日受付）

\section{Pathophysiological Studies of Jaundiced Yellowtail, Seriola quinqueradiata}

\author{
Yukio Maeno, Kazuhiro Nakajima, Minoru Sorimachi and Yasuo Inui
}

National Research Institute of Aquaculture, Nansei, Mie 516-01, Japan

(Received April 13, 1994)

\begin{abstract}
Hematological and histological studies were carried out on yellowtail, Seriola quinqueradiata, experimentally infected by intravenous injection of the bacterium causing jaundice of cultured yellowtail.

Hematocrit values and blood hemoglobin concentrations of the experimentally infected fish steadily decreased during 5 days after inoculation. In contrast, plasma hemoglobin and total bilirubin concentrations were maintained at a normal level during 3 days, but rapidly increased on the fifth day after inoculation. Histopathologically, the liver showed moderate focal necrosis and destruction of the endothelium of veins in moribund fish. The most extensive changes were observed in the spleen and kidney: severe anemia and necrosis in the splenic hematopoietic tissue, and degeneration and necrosis in the renal tubules and hematopoietic tissue were found. These pathological changes were similar to those observed in naturally infected fish. By indirect fluorescent antibody technique the bacteria causing jaundice were frequently detected in the spleen and kidney, but not in the hepatic parenchyma.

These findings suggest that in jaundiced yellowtail destruction of red blood cells by the causative bacteria resulted in increases in serum hemoglobin and bilirubin concentrations.
\end{abstract}

Key words : yellowtail, Seriola quinqueradiata, jaundice, bacteria, hematology, histopathology, hemolysis

前報（反町ら, 1993）において, 養殖ブリの“黄㾝症” 病魚から一種の細菌を分離し，感染実験の結果から“黄 疸症”は細菌に起因する疾病であることを明らかにし た。本研究では, 本症の病態生理を明らかにする目的で, 本症原因菌を接種した実験感染ブリの血液性状, 病理組 織および臓器における接種菌の動態を時間経過とともに 調べ, 併せて病理組織を自然発病魚のそれと比較検討 し，死に至る過程を考察した。

\section{材料および方法}

\section{実験感染魚}

供試魚には, 養殖研究所の陸上水槽で稚魚期（天然採 捕魚）から市販のブリ用配合飼料を投与して飼育したブ リ幼魚 30 尾 (平均体重 $203 \mathrm{~g}$ ) を用いた。接種菌液は, 香 川県下の黄㾝病魚から分離した原因菌を牛胎児血清

養殖研究所
(FCS : MAB) を 10\% 添加した L-15 培地 (Flow) に接種 し, $25^{\circ} \mathrm{C}$ で培養して調製した。実験感染魚には, 1 尾当 り $10^{6} \mathrm{cells} / 0.2 \mathrm{ml}$ の菌液を, 対照魚には実験開始時に FCS を 10\% 添加した L-15 培地のみを尾部血管内に接 種し, 市販配合飼料を投与して水温 $25^{\circ} \mathrm{C}$ で飼育した。 血液性状は菌接種 $1,2,3$ 日後の各 3 尾，5 日後の 5 尾, 対照として実験開始時に無処理の魚 3 尾および培地 のみを接種し, 実験感染魚と同様に飼育して 7 日後に取 りあげた 3 尾について, 心臓穿刺により採血して検査し た。ヘマトクリット值, 血液中および血漿中のへモグロ ビン量ならびに血漿中のビリルビン量は, 前報 (反町ら, 1993）と同様の方法で測定した。

病理組織学的検査には血液検查に供試した菌接種 1 , 2, 3 および 5 日後の各 3 尾と, 対照として実験開始時の 無処理の魚 3 尾および 7 日後に取りあげた 3 尾を用い た。供試魚の肝臓, 脾臓および腎臓の一部を摘出し, リ ン酸緩衝 $10 \%$ ホルマリン液で固定後, 常法に従い $4 \mu \mathrm{m}$ 
のパラフィン切片を作製し，マイヤーのヘマトキシリ ン・エオジン染色（H-E染色）を施して観察に供した。 黄疸原因菌を家鬼に免疫して得た抗黄疸原因菌家兔血清 を用いた間接蛍光抗体法により，各臟器における接種菌 の動態を調べた。

\section{自然発病魚}

自然発病魚については病理組織学的検査のみを行っ た。供試魚には, 1991 年 8 月に三重県のブリ養殖場で採 捕した体色の黄化, 鰓の貧血を主徴とする衰弱した黄疸 ブリ 2 年魚 4 尾 $(1,355 \sim 1,705 \mathrm{~g})$, および同年 10 月に香 川県下の養殖場で同様の症状を呈した 2 年魚 3 尾 $(2,265$ $\sim 2,840 \mathrm{~g}$ ) を用いた。対照魚として, 同時期に三重県下 の同一業者の黄㾝症状の全くみられなかった生筫から採 捕した 2 年魚 3 尾 $(1,530 \sim 1,665 \mathrm{~g})$ および香川県水試で 飼育されていた健康な 2 年魚 2 尾 $(3,005 \sim 3,200 \mathrm{~g})$ を用 いた。

供試魚から肝臓, 腎臓および脾臓の一部を摘出し, 実 験感染魚之同様の処理を施し, 組織学的観察に供した。

\section{結果}

\section{I. 感染実験}

\section{1. 実験経過}

黄疸原因菌を接種した供試魚は接種 2 日後までは肉眼 的には異常は認められなかったが， 3 日後から摄䭒が不 活発, 遊泳が緩慢となり，4 日後には体色が黒化した個 体が認められた。5 日後には死亡する個体が出現し, 生 残魚も体色が黒化し, 遊泳む不活発となって著しく衰弱 し，6 日後にはすべて死亡した。瀕死魚および死亡魚の いずれにも腹部の体色が黄化する特徴的な黄疸症状が観 察され，これらすべての供試魚の血液および脾臓から接 種菌が再分離された。対照魚は 7 日後まで全く異常は認 められなかった。

\section{2. 血液性状の経時的変化}

ヘマトクリット值：菌接種前のへマトクリット值は平 均 53.5\% であったが，接種 1 日後から徐々に低下し，5 日後には 8.7\% となった (Fig. 1)。

血中へモグロビン量：菌接種前の血中へモグロビン量 の平均值は $11.7 \mathrm{~g} / \mathrm{d} l$ であったが, 2 日後から減少し始 め, 5 日後には接種前の 3 分の 1 以下の $3.0 \mathrm{~g} / \mathrm{d} l$ に低下 した (Fig. 2)。

血漿中へモグロビン量：接種 3 日後までの平均値は $0.03 \mathrm{~g} / \mathrm{d} l$ から $0.08 \mathrm{~g} / \mathrm{d} l$ と接種前とほぼ同様の值を示した が, 5 日後には $0.31 \mathrm{~g} / \mathrm{d} l$ と急激に上昇し, $0.58 \mathrm{~g} / \mathrm{d} l$ と高

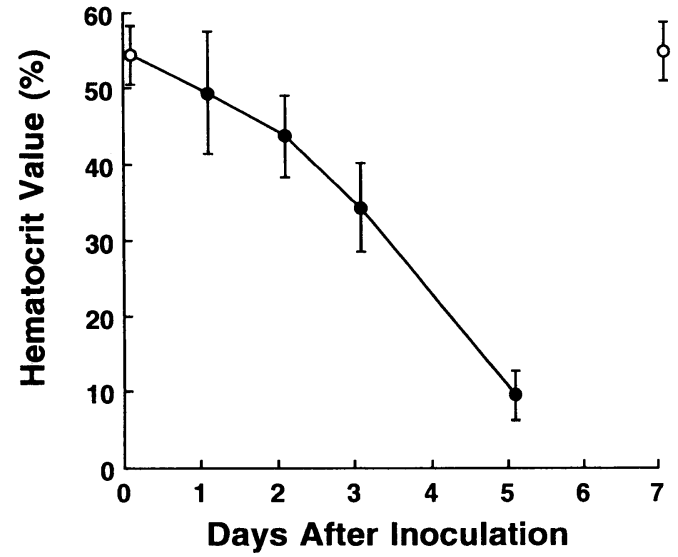

Fig. 1. Change in hematocrit values of fish experimentally infected with the bacterium causing jaundice. Vertical bars indicate S.D. ( $\bigcirc$ : Control on days 0 and 7)

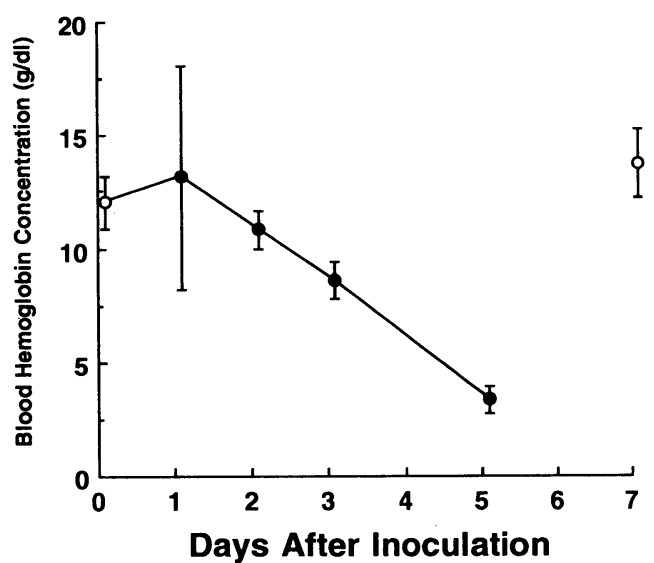

Fig. 2. Change in hemoglobin concentrations in the blood of fish experimentally infected with the bacterium causing jaundice. Vertical bars indicate S.D. ( $\bigcirc$ : Control on days 0 and 7)

い值を示す個体も認められた (Fig. 3)。

血墏中総ビリルビン量：接種 3 日後まではいずれの魚 あ血漿中の総ビリルビン量は $0.3 \mathrm{mg} / \mathrm{d} l$ あしくは検出限 界の $0.2 \mathrm{mg} / \mathrm{d} l$ 以下であったが， 5 日後には供試した 5 尾 いずれも $0.5 \mathrm{mg} / \mathrm{d} l$ 以上 (平均 $2.8 \mathrm{mg} / \mathrm{d} l$ ) となり, $5 \mathrm{mg} / \mathrm{d} l$ を越える個体む 2 尾認められた (Fig. 4)。

なお，対照魚として FCSを 10\% 添加した L-15 培地 のみを接種し， 7 日後に取上げた 3 尾のへマトクリット 值，血中へモグロビン量，血漿中へモグロビン量および 


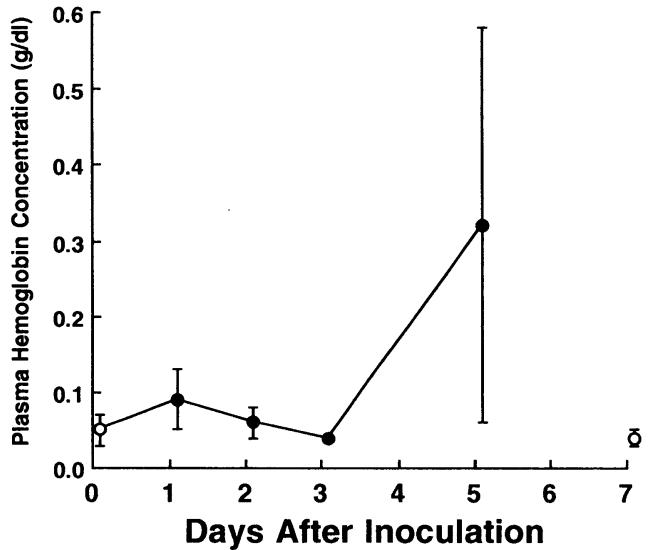

Fig. 3. Change in hemoglobin concentrations in the plasma of fish experimentally infected with the bacterium causing jaundice. Vertical bars indicate S.D. ( $\bigcirc$ : Control on days 0 and 7)

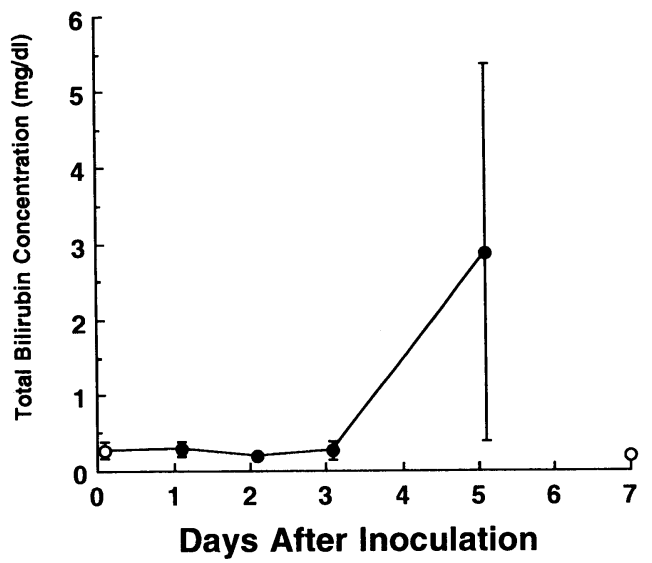

Fig. 4. Change in total bilirubin concentrations in the plasma of fish experimentally infected with the bacterium causing jaundice. Vertical bars indicate S.D. ( $\bigcirc$ : Control on days 0 and 7 )

血漿中総ビリルビン量の平均値は, それぞれ実験開始時 の無処理魚のそれらと同様の值を示した (Figs. 1 4)。

\section{3. 実験感染魚の病理組織像}

肝藏：接種 1 日後には明瞭な病理組織学的な変化は認 められなかった。2 日後にはいずれの個体においても局 所的な肝細胞の混濁化, 輪郭の不明瞭化が観察され, 核 濃縮も認められた (Fig. 5)。また，2 個体には肝静脈の血 管内皮細胞が変性し, 類洞に赤血球がうっ滞しているの が観察された (Fig. 6)。接種 3 日後には 2 日後と同様の
肝細胞および血管内皮細胞の変性像ならびにうっ血が認 められた。接種 5 日後にはすべての供試魚で肝静脈の血 管内皮細胞の変性像が認められたが，肝細胞の病変は 2 日後のそれと同様に概して軽微で局所的であった。

腎臟：接種 1 日後の 1 個体に局所的に尿細管上皮細胞 がエオシンに好染する像が認められた。接種 2 日後には 3 尾すべての尿細管上皮細胞に大型の硝子滴が明瞭に観 察された (Fig. 7)。尿細管上皮細胞の硝子滴変性は接種 3 日後にはさらに顕著となり，一部に核濃縮を伴った壊 死像が観察された。接種 5 日後には，1 尾に広範な尿細 管上皮細胞および糸球体の壊死 (Fig. 8) が, 他の 2 尾に おいては，尿細管上皮細胞の変性に加えて間質組織の出 血および壊死 (Figs. 9, 10) が観察された。

脾臓：接種 1 日後は明瞭な病理組織学的な変化は認め られなかった。2 日後には 1 個体に高度のうっ血が認め られた (Fig. 11)。3 日後には 2 日後と同様の脾内血管の うっ血が 1 尾に認められた。 5 日後には脾臟では髄質部 に核濃縮を伴う広範な壊死像が認められ，2 個体に極度 の貧血 (Fig. 12) が観察された。他の 1 個体には血球の 溶血像 (Fig. 13) および顕著な出血が認められた。

\section{4. 対照魚の組織像}

実験開始時および 7 日後のそれぞれ 3 尾について調べ たが，肝蔵，腎臓および脾臓にはいずれも実験感染魚で 観察された病変は認められなかった。

\section{5. 間接蛍光抗体法による各臟器における接種菌の動} 態

各㵴器における接種菌の動態を Table 1 に示した。脾 臟では接種 2 日後に菌体が認められた。その後菌数は増 加し，5 日後には脾臟䯣質部の広い範囲に陽性蛍光を呈 する多数の菌体が認められた (Fig. 14)。腎蔵では 3 日後 の 2 尾の間質組織に少数の菌体が検出され，5 日後には 菌数はやや増加したが脾蔵ほど顕著な増殖像は認められ なかった。一方肝蔵では 2 日後の 1 尾の肝内血管におい て菌体が認められ，以後 5 日後までいずれの個体の血管 内においても検出されたが (Fig. 15), 実験期間を通じて 肝実質組織では菌体は検出できなかった。各蔵器の血管 内の菌体は 3 日後から 5 日後にかけて急激に増加した。

\section{II. 自然発病魚の病理組織像}

三重, 香川両県の病魚の肝臓, 腎臟および脾臟におけ る病理組織像は一致していた。

肝臓：肝細胞の混濁腫脹および索状構造の乱れが観察 され，崩壊した組織は部分的に無構造，あるいは空胞化 を呈し (Fig. 16)，重度の個体では肝細胞に広範に崩壊， 

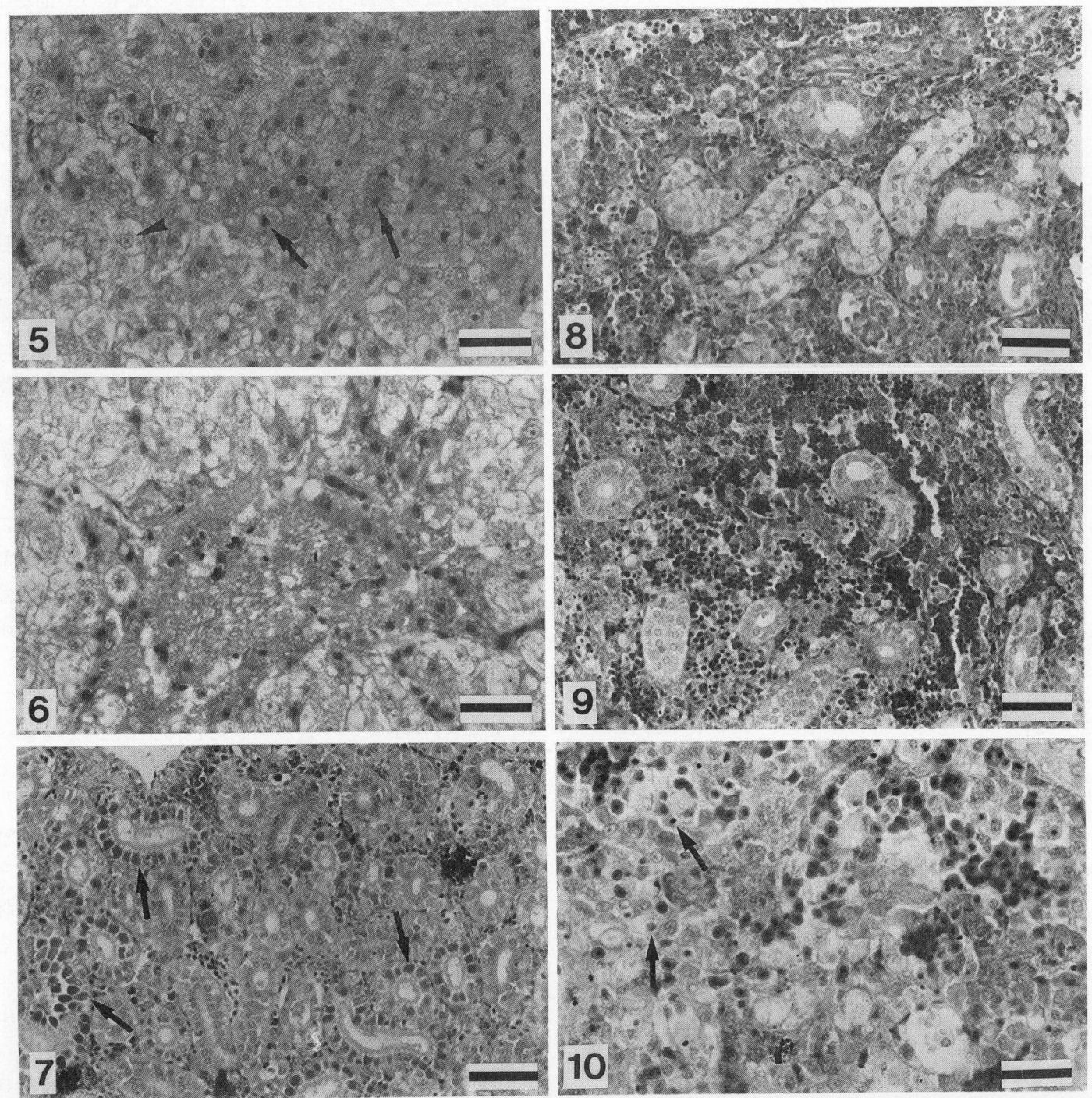

Fig. 5. Degeneration of hepatocytes in a fish inoculated with the bacterium causing jaundice on day 2 after inoculation. H-E stain. (Arrows, pyknotic nuclei; Arrowheads, normal nuclei) Scale bar $=20 \mu \mathrm{m}$.

Fig. 6. Impaired vein in the liver of a fish inoculated with the bacterium causing jaundice on day 2 after inoculation. H-E stain. Scale bar $=20 \mu \mathrm{m}$.

Fig. 7. Hyaline droplets (Arrows) in the cytoplasm of tubular epithelial cells of the kidney in a fish inoculated with the bacterium causing jaundice on day 2 after inoculation. H-E stain. Scale bar $=40$ $\mu \mathrm{m}$.

Fig. 8. Vacuolation and destruction of tubular epithelial cells of the kidney in a fish inoculated with the bacterium causing jaundice on day 5 after inoculation. H-E stain. Scale bar $=40 \mu \mathrm{m}$.

Fig. 9. Hemorrhage in the hematopoietic tissue of the kidney in a fish inoculated with the bacterium causing jaundice on day 5 after inoculation. H-E stain. Scale bar $=40 \mu \mathrm{m}$.

Fig. 10. Necrotic cells (arrows) in the hematopoietic tissue of the kidney in a fish inoculated with the bacterium causing jaundice on day 5 after inoculation. H-E stain. Scale bar $=20 \mu \mathrm{m}$. 

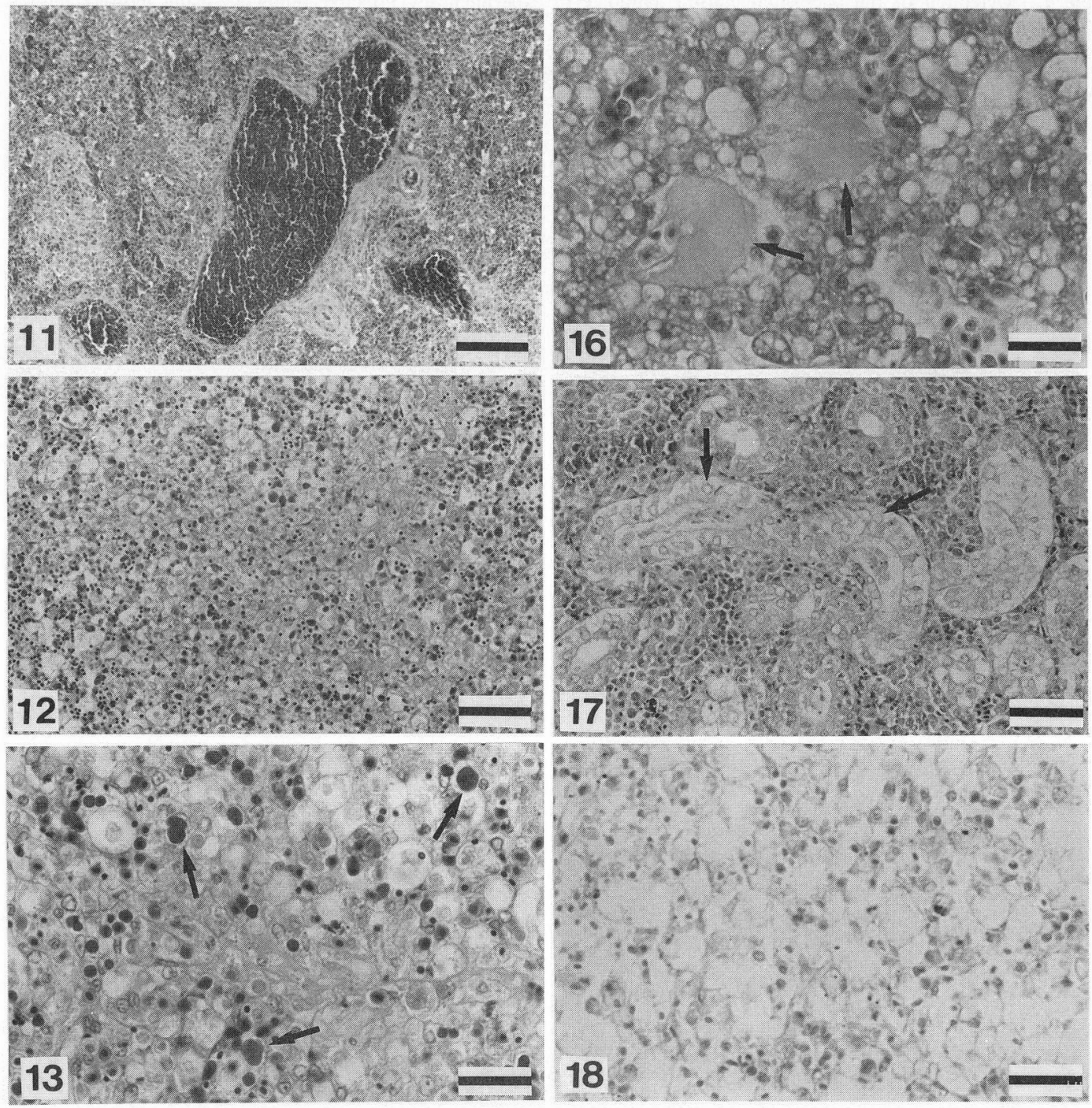

Fig. 11. Congestion in the spleen of a fish inoculated with the bacterium causing jaundice on day 2 after inoculation. H-E stain. Scale bar $=80 \mu \mathrm{m}$.

Fig. 12. Severe anemia with highly necrotic cells in the hematopoietic tissue of the spleen in a fish inoculated with the bacterium causing jaundice on day 5 after inoculation. H-E stain. Scale bar $=40 \mu \mathrm{m}$.

Fig. 13. Hemolysis (arrows) in the hematopoietic tissue of the spleen in a fish inoculated with the bacterium causing jaundice on day 5 after inoculation. H-E stain. Scale bar $=20 \mu \mathrm{m}$.

Fig. 16. Vacuolated hepatic tissue (arrows) and focal destruction of hepatic cell code in a naturally infected fish. H-E stain. Scale bar $=20 \mu \mathrm{m}$.

Fig. 17. Destruction of tubular epithelial cells of the kidney in a naturally infected fish. H-E stain. Arrows indicate degenerated nuclei. Scale bar $=40 \mu \mathrm{m}$.

Fig. 18. Anemia with highly necrotic and edematous tissue in the spleen in a naturally infected fish. H-E stain. Scale bar $=20 \mu \mathrm{m}$. 
Table 1. Detection of the bacterium causing jaundice in experimentally infected yellowtail using indirect fluorescent antibody technique

\begin{tabular}{|c|c|c|c|c|c|c|c|c|c|c|c|c|}
\hline \multirow{2}{*}{ Viscera } & \multicolumn{12}{|c|}{ Days after inoculation } \\
\hline & & 1 & & & 2 & & & 3 & & & 5 & \\
\hline Spleen & - & - & - & + & ++ & + & ++ & ++ & + & +++ & +++ & $++t$ \\
\hline Kidney & - & $-*$ & - & - & - & $-*$ & + & + & $-*$ & ++ & + & + \\
\hline Liver & - & - & - & - & - & $-*$ & $-*$ & -* & $-*$ & -* & -* & -* \\
\hline
\end{tabular}

$+\sim+++$; abundance of FA positive particles: - ; FA negative.

*; the bacteria were detectable only in the veins of each viscera.
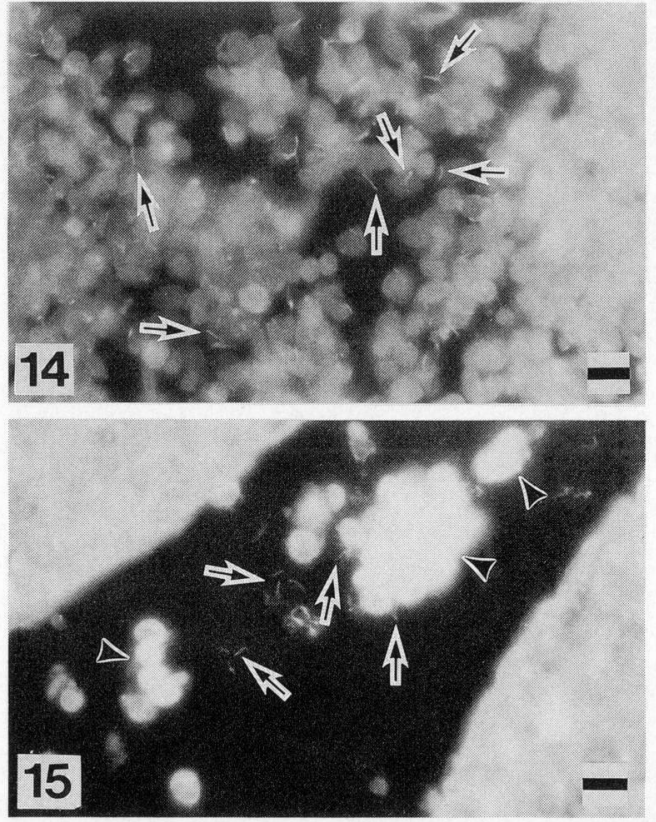

Figs. 14-15. The bacterium causing jaundice in experimentally infected yellowtail using indirect fluorescent antibody technique.

Fig. 14. The spleen of a fish on day 5 after inoculation. A large number of FA positive bacteria (arrows) are seen in the hematopoietic tissue. Scale bar $=10 \mu \mathrm{m}$.

Fig. 15. The liver of a fish on day 5 after inoculation. FA positive bacteria (arrows) are found in the vein, but no bacterium is seen in the hepatic tissue. Red blood cells (arrow heads) can be easily distinguished from FA positive bacteria by color under microscope. Scale bar $=10 \mu \mathrm{m}$.

消失しているのが認められた。

腎臓：尿細管上皮細胞の融解および基底膜からの剥離 が観察された (Fig. 17)。腎間質部は貧血状態を呈し，一
部の細胞に核濃縮が認められた。

脾臓：赤血球の減少, 䯣質部の細胞の核濃縮を伴う壊 死像が観察され (Fig. 18), 脾細胞の壊死が顕著であり, 水腫状を呈していた。三重県および香川県のそれぞれ 1 個体に溶血像が認められた。

三重県および香川県の対照魚の肝臓，腎臓ならびに脾 臓には，いずれも上記のような病変は観察されなかっ た。

\section{考 察}

前報において反町ら (1993) は, 養殖ブリの黄疸が未 同定の細菌による疾病であることを明らかにし，病魚は 鰓の著しい貧血, 脾臓の腫大, ヘマトクリット値の低下, 血中へモグロビン量の減少, 血漿中のビリルビン量の増 加が特徴であることから, 本症は溶血性の黄疸である可 能性が高いことを示唆した。

本研究において実験的に感染させた病魚の血液性状を 経時的に調べた結果，病状の進行とともにへマトクリッ ト值および血中へモグロビン量は顕著に隇少し，血漿中 のへモグロビン量および総ビリルビン量は著しく増加し た。これはブリに黄㾝原因菌が感染することによって赤 血球が溶血し, 結果として赤血球数が著しく減少したこ と, さらに赤血球の崩壊によってビリルビンが血中に急 激に蓄積したことを示唆している。津田ら (1994) は, ジ アゾ法によると溶血時に血漿中に現れるビリベルジン $\mathrm{IX}_{\alpha}$ が影響し，ビリルビン量が見かけ上高く測定される ことを指摘している。しかしながら，彼らの報告におい てもビリベルジン $\mathrm{IX}_{\alpha}$ のビリルビン量の測定值への影 響は相対的に軽微であることから，今回の結果は実験感 染魚の血漿中の総ビリルビン量の变動をかなり正確に反 映していると考えられる。これら実験感染魚におけるブ リの血液性状の变化は, 反町ら (1993) が自然発病魚お よび実験感染魚で観察した結果ともよく一致する。

ブリ正常魚の血液あるいは馬脱繊維血液を L-15 培地 
に添加して菌を培養すると，菌の増殖に伴い顕著な溶血 がみられる (未発表)。また病魚の血液塗抹標本では多数 の菌体が観察される。このことは, 本菌の増殖に血液が 深く関与しているとともに，本菌が溶血作用を有してい ることを示唆しているが，その機構は見在のところ不明 である。

実験感染でみられた主要臟器の病理学的変化のうち最 も特徴的な病変を示したのは脾臓および腎臓であった。 間接蛍光抗体法により脾臟では接種 2 日後から継続して 黄疸原因菌が多く認められたが, 接種 2 日後および 3 日 後の感染前半と死亡がみられる末期ではかなり異なった 組織像か観察された。感染前半には高度のうっ血がみら れたが, 脾蔵実質細胞には顕著な病理変化は認められな かった。これに対して末期には貧血がみられ，髄質部に 屯広範な壊死像か観察された。感染前半の脾㵴に大量の 血液が停滞していることはむしろ脾臓の機能六進，ある いは脾臓に血液処理の負荷がかかっているものと判断さ れる。これに対して末期の組織像は機能の退行, あるい は細菌の増殖による組織障害を示しているものと考えら れる。腎蔵では, 顕著な尿細管上皮細胞の壊死が認めら れる場合でも, 同部位における菌体は認められず，この 病変は本菌の感染による直接的なものではなく二次的な 変化と考えられる。これに対して出血および壊死がみら れた間質組織では菌の増殖が認められたことから，血液 ととあに侵入した細菌が組織に直接的に障害を与えたこ とを示唆している。一方肝臓の病変は, 肝実質細胞の局 所的な変性にとどまっており，自然発病魚にみられた肝 細胞の広範な崩壊，消失像は認められなかった。また菌 の存在は肝血管内に限られ, 肝実質組織においては全く 検出されなかったことから, 実験感染魚では本症の原因 菌は肝実質細胞には直接的な影響を及ばさないことを示 している。

間接蛍光抗体法による菌の検出が実験感染の初期から 各組織の血管内之脾蔵に顕著に認められたことは, 菌の 初期感染が血液と関連することを強く示唆している。特 に感染初期には脾臓に著しいうっ血がみられるが，実質 細胞には障害がみられないことは，脾臟においてはこの 時期に細菌によって障害を受けた赤血球の処理が元進し ていることを示唆しており, その後ビリルビンが増加す ることともよく一致する。これらの病理組織学的考察は 前述した血液学的考察とも合致するところであり, 本病 においては，一次的には血液における細菌感染により溶 血が起こりビリルビン血症を引き起こすむのと考えられ る。以上のことから本症は原因菌の感染による溶血が最
あ重要かつ特徴的な病態変化と考えられ，本症の病名を 細菌性溶血性黄疸と呼称することを提案する。

本研究で, 三重県および香川県のブリ養殖場で発生し た“黄㾝症”病魚の肝臓，腎臟抢よび脾臓における病理 組織学的変化を調べた結果, 両者は極めてよく一致して いた。すなわち肝臟では肝細胞の壊死, 腎蔵では尿細管 上皮細胞の硝子滴变性と壊死および間質組織の壊死, 脾 臓では䯣質部の壊死, 貧血なぞの病変が特徵的であっ た。自然発病魚の病理学的变化は実験感染魚のそれ之比 べ複雑な病理組織像を呈することが多かった。特に肝臟 ではこの傾向が顕著であり, 肝細胞の混濁腫脹に加えて 組織の崩壊と空胞化などが認められたが，このことは自 然発病魚ではかなりの長期間病態が継続していたことに よるあのと考えられる。

和田ら (1989) は体色黄化を特徴とする養殖ブリにお いて, 肝臓の類洞の拡張, 好酸性硝子滴状構造物の存在, 膠原繊維の増生, 小円形細胞の浸潤, 脾洞のうっ血なら びに肝臓，腎臟および脾臟におけるセロイド様色素顆粒 の沈着を主とする種々の病理変化を報告している。今回 の病理学的所見は, 上記の病変と類似するところあある が, 必ずしも一致しない。特に本研究では自然発病魚ば かりでなく実験感染発病魚においても肝臟および腎臟に セロイド様色素の沈着か認められなかったことから，こ れは黄疸にみられる特徴的な病変ではないと考えられ る。

黄㾝病魚の病理組織学的変化が，原因菌の侵襲による 直接作用によるものか, 溶血に伴うビリルビンの毒作用 あるいは血球残渣の排泄異常に基づく間接的なむのかは 明らかでない。また本病では原因菌の感染初期からの持 続的な溶血による過度の貧血状態が組織への酸素供給に あ不全をきたしていると考えられる。これらが相乗的に 働き血球の処理や血球残渣蛋白の代謝排泄に関わる脾蔵 や腎㵴に重大な影響をもたらしている可能性が強いと考 えられた。

\section{謝辞}

本研究の遂行にあたり, 種々のご協力を賜った三重県 水産技術センター尾鷲分場の故柴原敬生分場長, 三重県 引本漁協の杉本征史氏, 香川県水産試験場の松本紀男研 究主幹ならびに長野泰三主席研究員に感謝します。

なお本研究の一部は農林水産省 Preceded Research Program（プロジェクト研究調整費による研究 PRP9210-4）によって行われた。 


\section{文献}

反町 稔 - 前野幸男 - 中島員洋 - 井上 潔 - 乾 靖夫 (1993)：養殖ブリ “黄㾝症” の原因. 魚病研究, 28, 119-124.

津田友秀・村田 寿・境 正 (1994)：魚類血漿中のビ
リルビン含量はジアゾ法で測定すべきではない，日水 誌, 60, 131-132.

和田新平・畑井喜司雄・窐田三郎 (1989): 体色黄化を特 徵とする養殖ブリの光学顕微鏡所見. 魚病研究, 24 , 211-218. 